\title{
Abuso sexual: a criança em foco
}

\author{
Luana ConitoMuner - UnivesidadeSãoFramiso, Itatiba, Brasil.
}

Santos, C. A. (2012). Enfrentamento da reitimizaçãa a eata de cianças útimas de abuso sexual. São Paulo: Casa do Psicólogo.

O livro Enfretamento da reitimizaçãa a eata de cianças vítimas de abuso sexual, de Cristiane Andreotti Santos, é resultado de sua dissertação de mestrado defendida em 2009 pela Pontifícia Universidade Católica de São Paulo. No livro, a autora faz uma reflexão sobre as modalidades de inquirição judicial e as consequências disso para as crianças e adolescentes, dividindo-o em introdução e mais quatro capítulos.

No capítulo introdutório, a autora narra sobre 0 seu interesse inicial pelo tema e descreve as sequências dos capítulos. A sua experiência na Delegacia da Mulher, com atendimentos a crianças vítimas de abuso sexual incitou 0 interesse pelo tema, e especialmente pela angústia que relata sentir ao ver que as crianças eram submetidas diversas vezes a falar sobre a traumática experiência a que haviam sido expostas.

Iniciando o Capítulo 1, "O campo conceitual e 0 marco legal da violência sexual contra a criança", a autora traz uma perspectiva histórica sobre a infância, relatando que existem registros históricos de abuso infantil desde meados do século XIX. Durante anos, essa violência foi encoberta e rejeitada, procurando-se sempre outras explicações para as lesões encontradas. Cem anos depois, a violência contra crianças começa a ser visualizada. A autora discute os conceitos de abuso e violência sexual e a confusão gerada sobre eles na literatura, que ora usa-os como sinônimos, ora como coisas diferentes, além de ser um tema cercado de tabus, conceitos e temores. No livro, a autora dá preferência à utilização do termo violência com 0 cunho de "uma prática sexual traumática, que necessita ser estudada do ponto de vista psicológico, bem como uma prática ilegal, que fere a dignidade humana, sendo, portanto, matéria de exame no campo juńdico" (p. 25). Ainda nesse capítulo, a autora discute sobre a violência sexual no ambiente doméstico, que abarca a grande maioria dos casos de violência observados. Além disso, aponta as consequências da violência contra a criança, principalmente quando ocorre em casa, podendo ser consequências físicas e/ ou psíquicas. Nesse capítulo também é discorrido sobre os direitos da criança, fundamentados em leis propostas pela Declaração Universal dos Direitos Humanos, Pacto de San José da Costa Rica, Constituição Federal e Estatuto da Criança e do Adolescente.
No Capítulo 2, intitulado "O fluxo de atendimento à criança vítima de violência sexual e 0 processo de revitimização", a autora explica sobre 0 termo revitimização, que é utilizado por autores para designar que a vítima revive a situação do trauma quando tem que, por diversas vezes, relatar o ocorrido a pessoas diferentes. Nesse sentido, a autora aponta como acontece 0 andamento do processo de atendimento à criança vítima de violência, perpassando por diversos profissionais até chegar à solução final. Assim, demonstra a importância do psicólogo e seu acolhimento para a vítima nesse momento de fragilidade. Além disso, aponta para a importância de um bom trabalho interdisciplinar a fim de evitar maiores consequências para as crianças e adolescentes vítimas desse tipo de violência.

No terceiro capítulo, "O depoimento sem dano: uma proposta de inquirição", a autora toma como base o livro Depcimentosemdana altemativa para inquiir criancas eaddesentes nos proessos judiaais escrito pelo magistrado José Antônio Daltoé Cezar, explicando a proposta do depoimento sem dano, que é realizado no estado do Rio Grande do Sul visando diminuir os danos que podem ser gerados nas crianças e adolescentes vítimas do abuso sexual, diminuindo a sua exposição frente ao juiz, promotor, advogado e júri, além da exposição ao acusado. Aponta ainda, para outras alternativas que vêm sendo empregadas para a diminuição de danos que estão sendo realizadas em outros estados do Brasil e, em especial, em algumas cidades de médio e grande porte do estado de São Paulo.

O quarto e último capítulo, "Os debates entre a Psicologia e o Direito em torno da inquirição de crianças: uma abordagem crítica do material documental", apresenta o método utilizado pela autora na pesquisa de dados documentais realizada com a proposta de análise dos mesmos. São utilizadas diversas fontes, tais como artigos, reportagens, entre outros documentos, para a realização da análise de conteúdo com 0 intuito de organizar e sistematizar as informações que constam em tais documentos. A autora teve por objetivo demonstrar a tensão existente entre a área do Direito e as áreas da Psicologia e Serviço Social. Pela análise desses documentos, ratificase a importância do psicólogo nesse meio, visando o 
bem-estar e a melhor compreensão da criança em sua completude.

Por fim, a autora aponta para um desafio dos psicólogos, que é o de atuar no sistema jurídico a fim de promover a emancipação do indivíduo em sofrimento. Ressalta novamente a importância de não expor a criança, sujeito em desenvolvimento, a situações que a coloquem novamente em contato, causando-lhe assim a revitimização, dando foco a ela como sujeito e como pessoa em sofrimento; e de atuar da forma com que lhe cause menos danos, podendo-se utilizar a técnica do depoimento sem dano, a fim de minimizar sua exposição. Retoma, ainda, a importância do profissional da psicologia diante o meio jurídico.
O livro traz um debate interessante sobre a psicologia relacionada principalmente com a área do Direito e das Ciências Sociais. Traz conceitos relativamente novos para áreas tão distintas e antigas, focando principalmente no bem-estar das crianças e adolescentes, que muitas vezes podem ser esquecidos como sujeitos no decorrer do processo, sofrendo a revitimização por profissionais que têm a teoria, mas não sabem lidar na prática com esse público diferenciado e fragilizado por diversas questões. É uma leitura necessária por sua contribuição para a psicologia jurídica, principalmente no que se refere à psicologia junto à Vara da Infância e Família.

Sobre a autora:

Luana Comito Muner é mestranda em Avaliação em Psicologia Educacional do Programa de Pós-Graduação StridoSensu em Psicologia da Universidade São Francisco. Bolsista CAPE S-O bservatório da Educação.

Contato com a autora:

Travessa D outor Affonso Augusto Santangelo, 37, CEP: 12.916-230. Bragança Paulista, São Paulo. Email: lumuner@hotmail.com 